\title{
Morphogenesis in vitro and peroxidase activity in barley cv. Steptoe and its ABA-deficient mutant AZ34: effects of inhibitors of ABA synthesis and auxin transport \\ Seldimirova O.A., Kudoyarova G.R., Galin I.R., Veselov D.S., Kruglova N.N. \\ Ufa Institute of Biology, Ufa Federal Research Center of RAS, Ufa, Russia \\ E-mail: o_seldimirova@mail.ru
}

\begin{abstract}
Key message. The relationship between the effect of ABA on morphogenesis in vitro and auxin transport, as well as the role of peroxidases in the action of ABA on morphogenesis in vitro in the ABA-deficient barley mutant AZ34 and its parent form cv. Steptoe was studied.
\end{abstract}

Keywords: morphogenesis in vitro, ABA, peroxidases, ABA synthesis inhibitors, auxin transport inhibitors

The effect of reactive oxygen species (ROS) and auxin transport inhibitors on morphogenesis in vitro is not well understood. The aim of the work is to identify the role of ROS, as well as hormones and their functional interaction in the regulation of morphogenesis in vitro. The ABA-deficient mutant AZ34 and its parent form cv. Steptoe were used as objects of study. The methods of callus culture in vitro, vital histochemical staining using 3,3-diaminobenzidine (DAB) and histological studies were used. The use of the DAB staining with the addition of exogenous hydrogen peroxide revealed a high level of peroxidase activity in the cells of the callus meristematic zones (the initials of various morphogenesis pathways in vitro). It was established that on the basic nutrient medium in Steptoe calli normal embryoids were formed, and in AZ34 they were delayed in development and were characterized by a decrease in peroxidase activity, which was offset by the addition of exogenous ABA to the medium. In contrast, the addition of an inhibitor of ABA synthesis fluridone was delayed the development of embryoids in Steptoe calli and decreased peroxidase activity. In general, a relationship was found between the level of ABA and peroxidase activity, which can be explained by the ability of this hormone to increase peroxidase activity. There is evidence that the effect of ABA on morphogenesis in vitro is due to the suppression of auxin transport under the influence of ABA. The addition of naphthylphthalamic acid to the medium induced abnormal rhizogenesis in AZ34 and abnormal embryoidogenesis in Steptoe and could not mimic the effect of ABA, which indicates a more complex role of this hormone than inhibition of auxin transport. Adding vanadate (an $\mathrm{ABC}$ transporter inhibitor) to the nutrient medium induced gemmorhyzogenesis in both genotypes that differ in their ability to synthesize ABA, which indicates that ABA is not involved in the regulation of auxin transport involving $\mathrm{ABC}$ transporters. The obtained results allow us to conclude that $\mathrm{ABA}$ plays an important role in the regulation of morphogenesis in vitro, however, the mechanism of action of ABA on this process cannot be explained only by the effect of this hormone on auxin transport.

The work was carried out through the state task of Ministry of Science and Higher Education of the Russian Federation, the project no. 075-00326-19-00 according to theme AAAA-A18-118022190099-6.

\section{Морфогенез in vitro и активность пероксидаз у ячменя сорта Steptoe и его АБК-дефицитного мутанта AZ34: влияние ингибиторов синтеза АБК и транспорта ауксинов \\ Сельдимирова О.А., Кудоярова Г.Р., Галин И.Р., Веселов Д.С., Круглова Н.Н. Уфимский Институт биологии УФИЦ РАН, Уфа, Россия}

\begin{abstract}
Аннотация. Изучено наличие связи между влиянием АБК на морфогенез in vitro и транспортом ауксинов, а также роль пероксидаз в действии АБК на морфогенез in vitro y АБК-дефиџитного мутанта ячменя АZЗ4 и его родительской формы - сорта Steptoe.
\end{abstract}

Ключевые слова: морфогенез in vitro, АБК, пероксидазы, ингибиторы синтеза АБК, ингибиторы траспорта ауксинов

Влияние активных форм кислорода (АФК) и ингибиторов транспорта ауксинов на морфогенез in vitro изучено недостаточно. Цель работы - выявление роли АФК, а также гормонов и их функционального взаимодействия в регуляции морфогенеза in vitro. В качестве объектов исследования использовали дефицитный по АБК мутант АZ34 и его родительскую форму - сорт Steptoe. Применяли методы каллусной культуры in vitro, витального гистохимического окрашивания с использованием 3,3-диаминобензидина (ДАБ) и гистологических исследований. Использование красителя ДАБ с добавлением экзогенной перекиси водорода выявило высокий уровень активности пероксидаз в клетках меристематических зон каллусов (инициалей различных путей морфогенеза in vitro). Установлено, что на базовой питательной среде в каллусах Steptoe, формировались нормальные эмбриоиды, а у AZ34 - задерживались в развитии и характеризовались снижением активности пероксидаз, что нивелировалось добавлением в среду экзогенной АБК. Напротив, добавление среду ингибитора синтеза АБК флуридона задерживало развитие эмбриоидов в каллусах Steptoe и снижению активности пероксидаз. В целом, выявлена связь между уровнем АБК и активностью пероксидазы, что можно объяснить способностью этого гормона повышать активность пероксидаз. Имеются сведения, что влияние АБК на морфогенез in vitro обусловлено подавлением транспорта ауксинов под влиянием АБК. Добавление в среду нафтилфталамой кислоты индуцировало аномальный ризогенез у AZ34 и аномальный эмбриоидогенез у Steptoe и не смогло сымитировать действие АБК, что свидетельствует о более сложной, чем ингибирование транспорта ауксинов, роли данного гормона. Добавление в питательную среду ванадата (ингибитора АВС транспортеров) к индукции гемморизогенеза у обоих генотипов, различающихся по способности к синтезу АБК, что свидетельствуют о том, что АБК не принимает участия в регуляции транспорта ауксинов с участием АВС-переносчиков. Полученные результаты позволяют сделать вывод о важной роли АБК в регуляции морфогенеза in vitro, однако механизм действия АБК на этот процесс нельзя объяснить только влиянием этого гормона на транспорт ауксинов.

Работа выполнена в рамках государственного задания Минобрнауки России № 075-00326-19-00 по теме № AAАA-А18118022190099-6. 